\title{
Rajdeep Singh, the Peace Poet: Analysis of Figurative Language Used in 'La paz que venga con fuerza' Poem by Rajdeep Singh
}

\author{
Rajdeep Singh \\ M.A of Regional Studies, University of Tehran, Tehran, Iran
}

\begin{abstract}
This paper deals with the ideological and cultural positioning of Iranian poet Rajdeep Singh in his famous poem "La paz que venga con fuerza". We adopt the emerging branch of linguistics, called cognitive analysis, and we also develop a semantic map in order to uncover the great ocean of metaphors in the poem. He is one of the few Middle-Eastern poets who write primarily in Spanish and English, leading the poetical new wave in Iran. One of the goals of the present study is to expose some of the implied meanings and ideological stances the poet adopted concerning the peace and also the linguistic choices he used to twist meanings and create environment for mystic thoughts. The present analysis disposes of different cognitive tools which, after being applied, show clearly how the poet aesthetically used different macro-structural and micro-structures devices to deliver his sincere call for the inner peace in the modern life.
\end{abstract}

Keywords: poem, cognitive analysis, semantics, ideology, peace, macro-structural meaning, content analysis DOI: $10.7176 / J L L L / 53-01$

\section{Resumen}

Este artículo se trata del posicionamiento ideológico y cultural del poeta iraní Rajdeep Singh en su famoso poema " La paz que venga con fuerza ". Adoptamos la rama emergente de la lingüística, llamada análisis cognitivo, y también desarrollamos un mapa semántico de una maniera clara y illustrativa para descubrir el gran océano de metáforas unicas de este poema. Él es uno de los pocos poetas de Oriente Medio que escriben principalmente en español e inglés, liderando la nueva ola poética en Irán. Uno de los objetivos del presente estudio es exponer algunos de los significados implícitos y posturas ideológicas que el poeta adoptó en relación con la paz y también las opciones lingüísticas que utilizó para torcer los sentidos y crear un entorno para los pensamientos místicos. El presente análisis dispone de diferentes herramientas cognitivas que, después de ser aplicadas, muestran claramente cómo el poeta utilizó estéticamente diferentes dispositivos macroestructurales y microestructuras para lanzar su sincero llamado a la paz interior en la vida moderna.

Palabras claves: poema, análisis cognitivo, semántica, ideología, paz, significado macroestructural, análisis de contenido

\section{Introduction}

Mixing languages in the poetic endeavor is not common and there are few poets that dare to go through the difficulties of expressing themselves in different modes of language device. Toribio (2004) conducts a linguistic analysis of Spanish-English bilingual speech by surveying several outcomes of language contact, among these, inter-lingual transference, code switching, and convergence, as evidenced in the speech practices of heritage Spanish speakers in the United States. Toribio (2004) investigates numerous poems and claims regarding one of the poems that "Numerous and varied themes arise in the interpretation of this poem, some oriented towards content, and others focused on linguistic form. At one level, the poem is an indictment of the educational system, at another, the linguistic modulation of the poem represents the difficulty of marking out an 'interlingual' space". As it is discussed by Toribio, the poems help learning about the inter-lingual space and the way language affects the emotions of bilinguals. On the other hand, the requirements of the authorship and the way writers interact with their readers have been pursued by some researchers. Martínez-Ávila, Smiraglia, Lee and Fox (2015) discuss and shed light on the following questions: What is an author? Is it a person who writes? Or, is it, in information, an iconic taxonomic designation for a group of writings and how does that accord with the manner in which the data have been entered in association with the names of the entities identified with the concept of authorship? And they conclude that an "author" is an iconic name associated with a class of works, being a role in cultural sublimation.

Hamdi (2015) conducts a cognitive study of happiness metaphor in English, Tunesian Arabic and Spanish, adopting the Conceptual Metaphor Theory (CMT), as proposed by Lakoff and Johnson (1980). Hamdi uses different methodological tools in the model such as "conceptual metaphors", "linguistic metaphors", and "cognitive transfer", while claiming that the results suggest that English, Tunisian Arabic and Spanish share many conceptual metaphors for happiness, such as happiness is a fluid in a container, happiness is light, happiness is being off the ground and the differences can be attributed to cultural differences.

Miranti and Nur (2018) investigate different kinds of figurative language in the selected poetry of Maya Angelou, entitled Still I Rise. They focus on the figurative language involving: Metaphor, Personification, 
Hyperbole, Simile, Metonymy, Synecdoche, Irony, Antithesis, Symbolism, and Paradox. They chose qualitative approach through the content analysis in order to demystify the various hidden meanings behind the text. Qualitative approach with design of content analysis was used in this study. They conclude that the figurative language in the form of poetries told about her experience in the past was deeply rooted in the history of the discrimination of American-African.

Singh (2018) investigates the notion of semantic-cognitive meanings behind the different cultural and religious terms, available in many languages. He shows how language learners' errors of Hausa and Spanish are deeply rooted in their first language. Poems, popular in the Middle-East and Indian sub-continent, have proved to be connected to the manner learners connect their already acquired concepts to the new coming ones. Singh (2018) also points out to the mirroring effect, common in many cultures, that helps making new words. He also introduces the semantic-cognitive load function which he claims to play an important role in the different cognitive and psycho-linguistic processes.

Munawar and Rafique (2016) analyze the poem "The Stone Chat" by Taufiq Rafat, a prominent Pakistani poet, adopting the structuralism (a Linguistic movement related to scientific study of words as signs) as a theoretical framework. Their study focuses on, presenting Structuralistic analysis of the selected text, as proposed by the Swiss Structuralist, De Saussure. Besides, they run a textual analysis of different pieces of poetry by application of binary opposite concept. In doing so, they focus on the different forces, such as the antithetical ones, and other ideas in the text. They analyze the variations in tone, attitude and thinking perspectives of speaker in the poem.

Much has been written and analyzed from ethnographic and social perspectives concerning English and Spanish mixed poems. However, far less has been written concerning Spanish-English mixed poems in countries where these languages are not the native languages. Many literary critics describe poems written by non-native poets as less charming. Poems are the soul of poets, substantiated in a vocal message. This seems a glassy, emotionless claim unless one can distinguish by the characteristics the best poems written by native and nonnative poets. Finding those determining features is not an easy task and there have been many different criteria as to what constitutes a good poem. Establishing a baseline to analyze and compare poems and story-telling can be the first step towards a more just regard toward poems and artistic written creations, but it is not enough.

It is not enough to classify poems based on specific features as there have been many great poems that are just simply ignored because of some specific criteria-based reasons. What we suggest is that poems, regardless of the author, should be regarded first as the emanations of the soul, not measurable by specific features. We will focus on a beautiful Spanish-English mixed poem, written in Iran, by poet Singh, which offers itself as a classic case for the investigation of the practicality of poems written in a very different, foreign environment. This poem that has links to Persian and Indian drama constitutes a great piece connecting the East and West in a rather universal way.

We will analyze how this poem connects with the more traditional Eastern concepts as well as how it diverts away from that monolithic tradition. This paper is specially a textual analysis of this Iranian poem, illuminating some of the novel and so called new-wave type of poem in the Iranian society. we will also investigate the way this poem produces some feelings of distance and pain, taking into consideration the codes or languages used in this poem and the ideologies that the poet somehow brings to the public that motivate decisions as which language, and which mode of expression is appropriate. The following is the poem "La paz que venga con fuerza".

1) The empty rooms, the cold blooms.

The peeling paint, amazing restraint.

The weathered floorboards, the broken chords .

All the voices, so distant, so faint.

2) The broken windows, the betokened arrow.

The broken heart, the unspoken start.

The open doors, the torturing sore..

3) Empty rooms, cold blooms, Jamas regresarias...(3.1)

Pealing paint, dolor picante...

Weathered floorboards, que hago hermanos...

Voices, que pena...

Distant, como la madrugada no existe.. .

Faint, que suerte..

4) Broken windows, la ventana cerrada...

Open doors, no siento voces...

Mental prison, no es mi casa...

Broken shelter, puedes escaparte...

Ravaged, como fuego... 
By the storm, ay que hermoso.

5) Voices, no se acabaron...

Gather volume, que me duele...

Just as the sky begins to crack, no camina conmigo el futuro...(5.2)

Screaming, walking, sin fuerza eternamente...(5.3)

Panic. Sin drama dime..

Anxiety attack, que veo mi casa en fuegos...

6) Return it, que regresen mis hermanos, que vayan dolores pronto...(6.1)

Back inside it shall go, no es tan brillante...

Thank the flag so black, que me salvo asi tanto...(6.3)

For the things people do not know, ignorancia no es respuesto...

7) Then lighting lit the earth, ah donde es tierra perdida en mi Corazon?

The sky thundered, mi alma se fue an aire...

The moon's glow concealed, esconder no puedo lo que no esta aqui...

Overcast, fuerte castigo...

Heaven conquered, el paraiso sin color.

8) Voices, voces que no se sienten...

Just memories, memorias de otro dia...

Louder they become, que ne cesen...

Voices, voces, que pena...

In my head, mi cabeza es perdida...

Unravel me, muestrame el camino...

Undone, no me imagino...

9) Empty rooms, el amor perdido...

Hollow sound, que me escuchen..

Shadowed corridor, en mi calle corren...

Memory, memoria, alegria ...

Found, no es tan perdida...

10) Alone inside, many times tried, que hagan aqui fiesta...

Sitting on the floor, que animen mi Corazon.

Memories they flood me, memorias corren con la revolucion.

Too excruciating to ignore, asi es mi destino.

11) Block the voices! Que digan lo que quieran!(11.1)

Scream out in rage! Que bailen como nunca!(11.2)

Look for the morrow, the lost glow, mi mundo es negro...

12) donde estabas tan cubierta..(12.1)

dime como puedes regresar con tu sonrisa.(12.2)

llevando a la agua mi tristeza, tu sonrisa. (12.3)

no mezcles mi alma con tu ira. (12.4)

como pinto lo que siento en esta sociedad dormida...(12.5)

donde no existe la mas querida en tiempo de guerra...(12.6)

13) lo que mas desiro.

la paz, mi sonrisa.

sin cesar me digo, que vendrias.

porque has retrasado tanto...(13.4)

14) cuando vengas, escondes tu sonrisa. (14.1)

aqui la gente no ha visto sonrisa.

la Guerra no es tan dolorosa...

la paz, vas a ver como Guerra es bella.

cuando estas aqui, no me robes la alma.(14.5)

pues somos avezados a dolores sin pausa...

\section{Analysis}

In this poem, the author arranges the scene in a way that the reader feels participating in the flow of events, unconsciously following the events. The reader perceptibly is put in the viewing position, experiencing the feelings of the consciousness of the author. The reader gets a chance to imagine the dramatic scene that the author is drawing silently before her eyes. If the latter gets distracted a bit, the undercurrent of the story catches her attention; so the reader lets herself swims in the ocean of consciousness that this poem created.

The reader brings all her background knowledge, switching from Spanish to English, adopting the stance of 
the author finally along the internally constructed scene. The view point remains chiefly constant with the exception of background battle that sometimes becomes intense and times comes in guise of peace. In fact, the reader is faced with an internal struggle in the Spanish lines. While she begins the poem with English as she progresses and getting involved more intensely with the text, she gets to see everything gradually in Spanish; we see a trend from English to Spanish, both in the lines and the mega-structure of the text.

The author avoids using the personal pronouns and instead tries to connect to the reader through emotions expressed in the shape of adjectives: dolorosa (painful), bella (beautiful), empty, cold and many more. While as to bring the reader in author's view point the poet employs the empathic device and self-inquiry which allows the reader to feel at home and to take part in the quasi-theatrical play. The author paints the scene, making himself the bearer of good and bad news, depending on what the reader feels closer to realize in the text; he uses adjectives such as distant to psychologically commit the reader to go against the default position, getting closer to the scene. He makes himself as though there was a guest called peace which is waiting to get a chance to visit his society. When referring to the peace, the author makes the stage ready for the smile, sonrisa to come in line (14.1). The author uses the demonstrative aqui (here) in order to create the deictic center which is himself and those he represents.

Regarding time, the poet uses the verb retrasar(delay) and time adverbial pronto (soon), nunca, jamas (never) and adverb eternamente(eternally), all showing the beautifully realized context for the meaning to grow and spread from the beginning to the end lines of the text, similar to the overall context of the poem (i.e retrasado, line 13.4;pronto, line 6.1 ; eternamente, line 5.3, jamas, line 3.1;nunca, line 11.2 ). We will now proceed to analyze the cognitive meaning of some of the concepts found in this poem.

\section{Peace}

One of the notions that this poem entertains is peace. The influence of civil society in various phases of peace process is undeniable. There is always a tension between what the elite considers as the peace and what the layman desires to reach. Though here, the poet delivers a rather internal concept of peace, which transcends all the barriers and obstacles on the way. It is this inner-most silent type of peace that the poet lauds to the sky.

$\mathrm{He}$ is inviting the peace to be a real guest in his home, while he doesn't explicitly name any designated home. Even if we look at the political peace process, it gets clear that there is never any clear goal out of the negotiations. What remains to be achieved is the mere silence of guns, in other words the disappearance of hostility. Somehow this line of defense for peace is what the author delivers to the reader. There is a certain feeling of detachment and calm in his approach to the peace, largely away from heated debates and political sidetakings.

He invites the reader and larger civil society groups who struggle for peace to get in. In fact, he gradually builds up his peace scheme out of tiny bits of meaning blocks such as broken window and ventana cerrada (closed window). The author pushes for more coherence in the peace character, using the noun sonrisa (smile) to describe it. He indirectly engages the reader to picture the peace as a smile in a hostile environment, something hard to imagine, but put into words in a fashionable manner. The cognitive analysis of some of the notions tied with the peace is illustrated in the following figures.

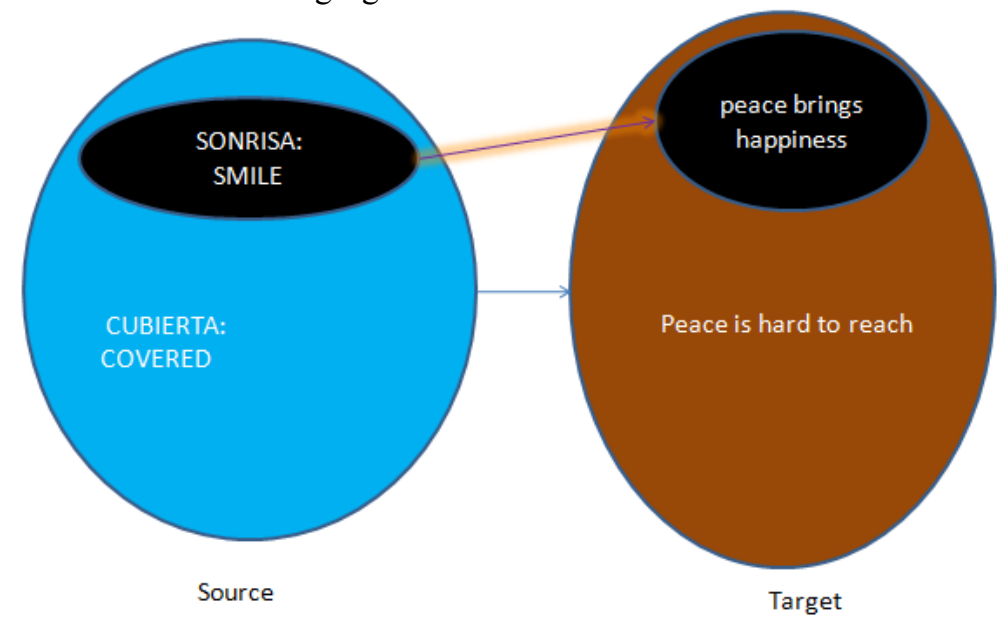

Figure1. Peace concept (lines $12.1 \& 12.2)$ 


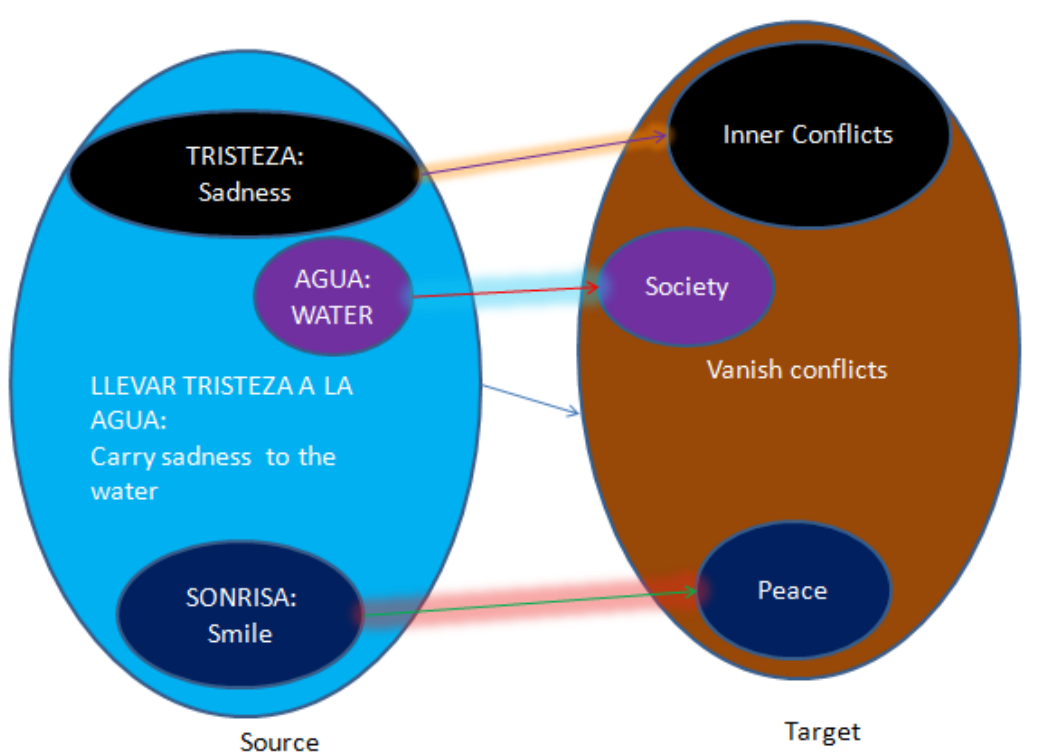

Figure2. Source to target, peace and conflict concepts (line 12.3)

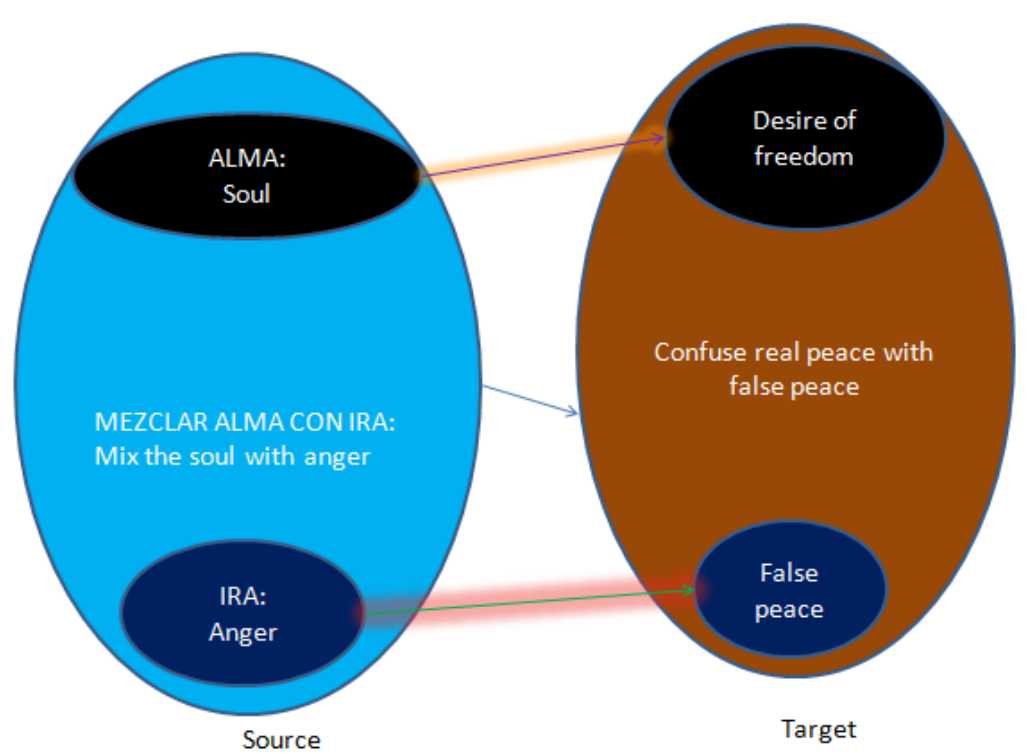

Figure3. Source to target, false peace and anger concept (line 12.4) 


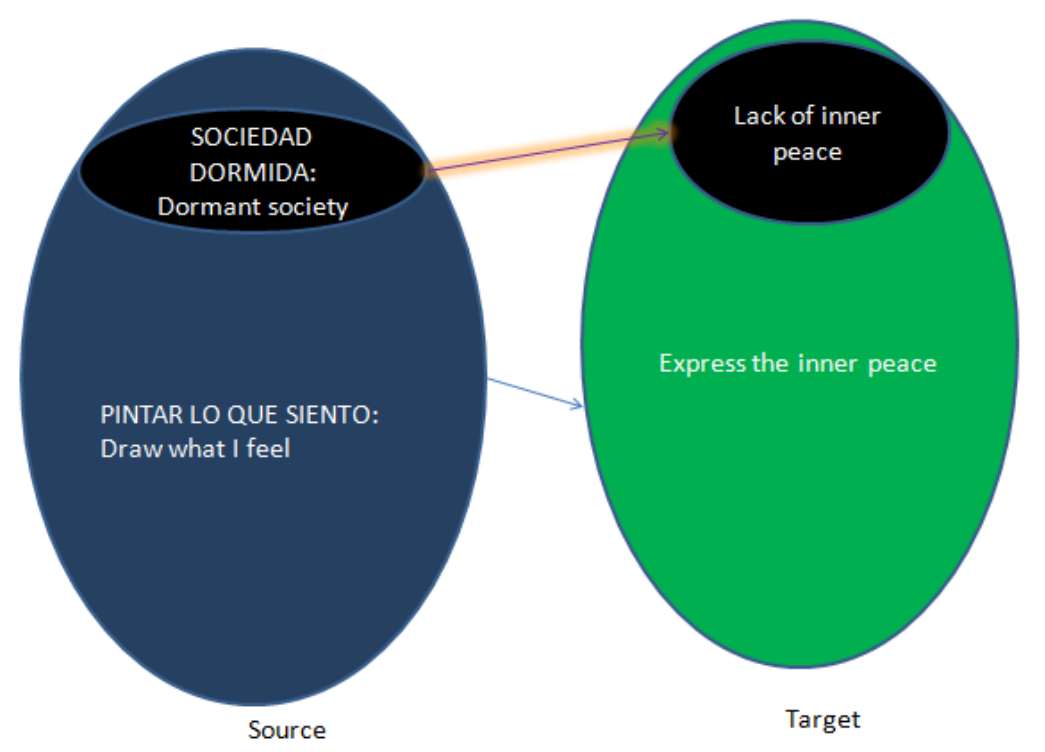

Figure4. Source to target, dormant society and peace concept (12.5)

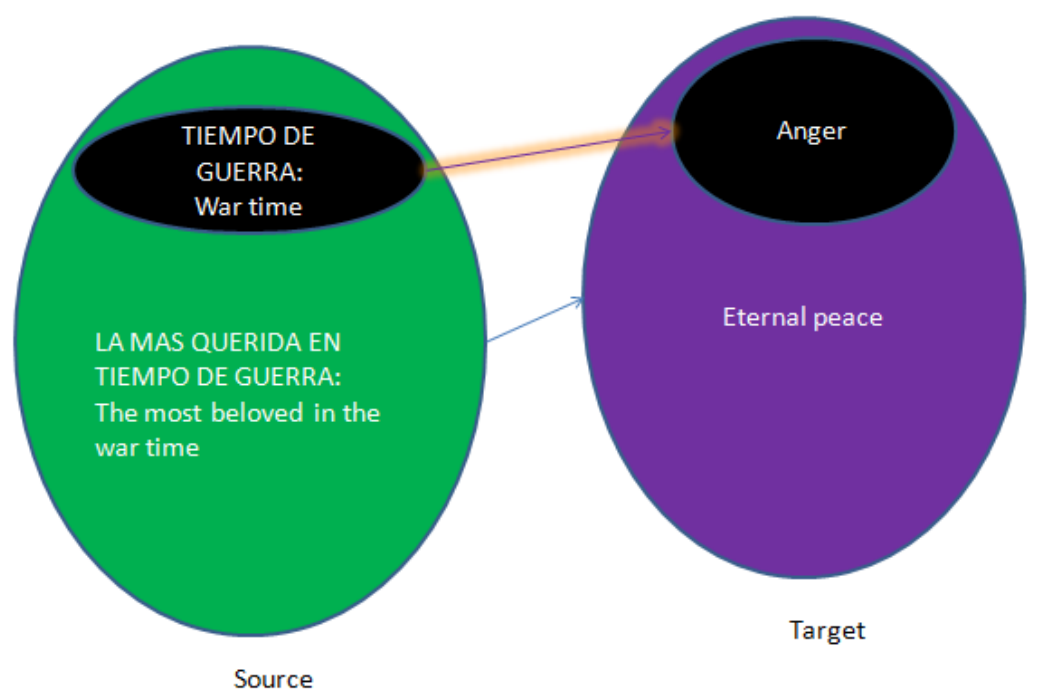

Figure5. Source to target, wartime and peace (line 12.6)

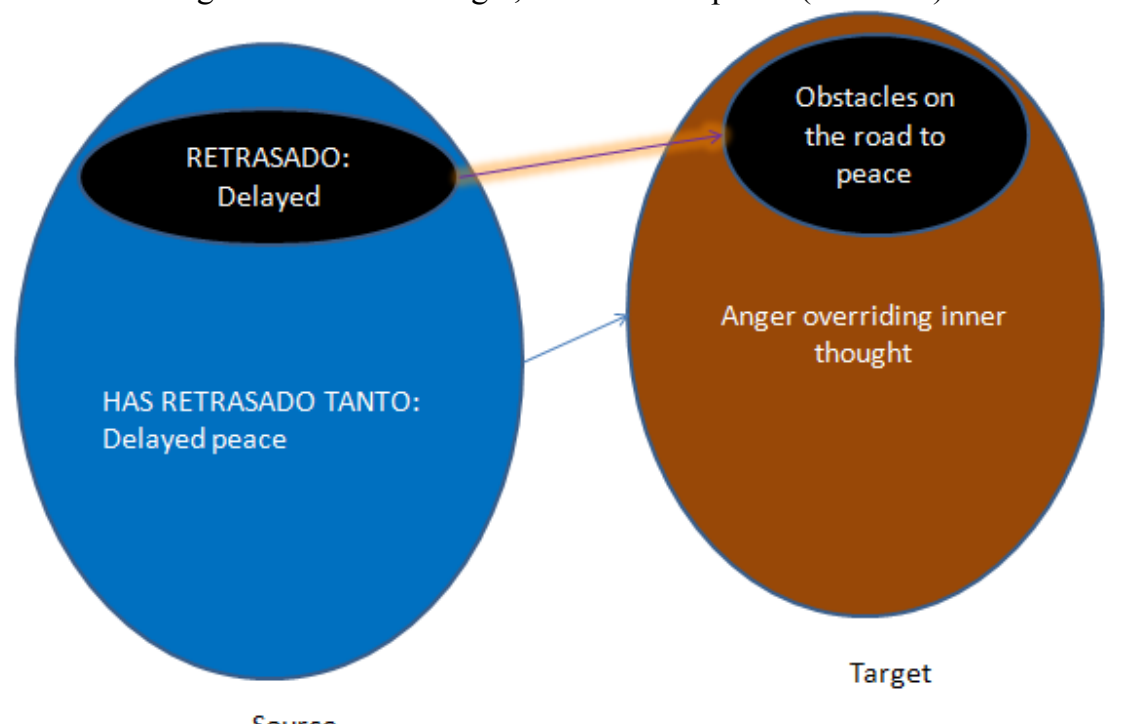

Figure6. Source to target, delayed peace and obstacles concept (line 13.4) 


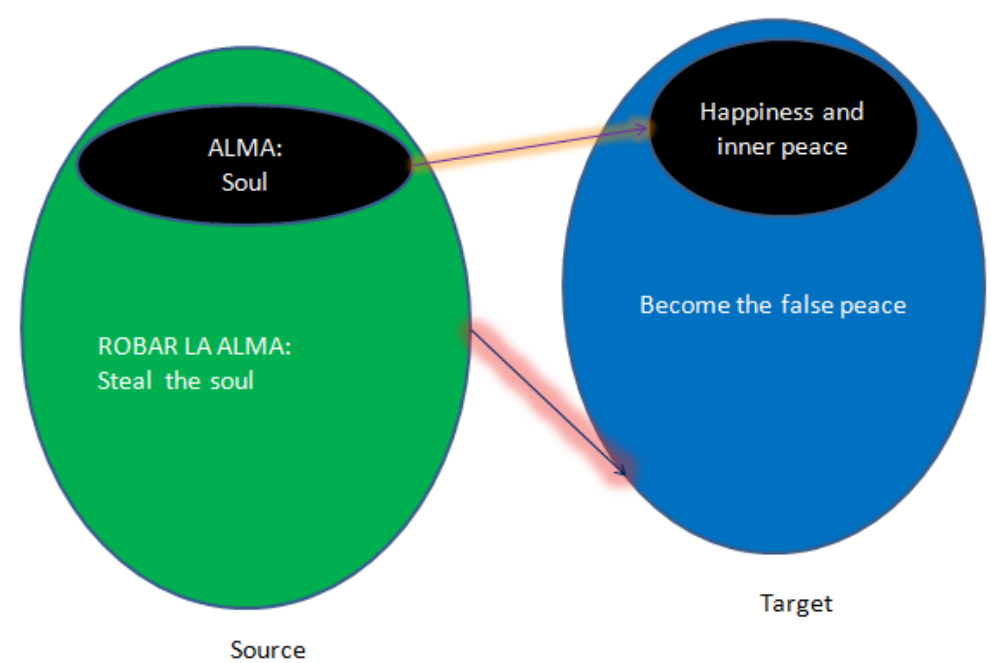

Figure7. Source to target, stolen soul and peace concept (14.5)

\section{Conclusion and Results}

The analysis shows that through the representation of peace in different forms and shapes, from dormant to the most vibrant smiling one, the author places the reader in the most advantageous position to observe the interplay between the author's consciousness and her own realities and background knowledge. The author's ideology of peace as the inner hidden calm kept away from the harsh reality of the outer world invites the reader to imagine a world where the eternal peace of mind reigns. In many places in the text, the reader is placed in the deictic center as she gets engaged with the interesting, back and forth inner speech of the author and herself. The gradual change of language from English to Spanish, and the clear end point, with is la Paz (the peace) has a great impact on the reader, describing a deep river from the uphill to the downhill. Moreover, generally speaking, the ideological stance of the poet transcends the common political side-takings as the poet draws a story full of inner-thoughts and away from the general politicized society. In this sense, poet presents a pristine picture of the intramural world, without going out to look at the every details of everyday life. It can be said that the poet builds a safe bunker under the unpleasant reality. His ideological stance was also investigated through the cognitive linguistics and model which connects the source to target in a clear visual way.

\section{Reference}

Hamdi, S (2015). A Cognitive Study of Happiness Metaphors in English, Tunisian Arabic and Spanish. Arab World English Journal (AWEJ).Vol.6, No.1. https://dx.doi.org/10.24093/awej/vol6no1.11

Martínez-Ávila, D., Smiraglia, R., Lee, H. L., \& Fox, M. (2015). What is an author now? Discourse analysis applied to the idea of an author. Journal of Documentation, 71(5), 1094-1114.

Miranti, R., R. \& Nur, M., R., O. (2018). The Analysis of Figurative Language Used in 'Still I Rise' Poem by Maya Angelou. International Summit on Science Technology and Humanity (ISETH 2018).

Munawar, B.; Rafique, H. (2016). Structuralist Analysis of the Poem "The Stone Chat" by Taufeeq Rafat in perspective of Binary Opposition. Int. J. Appl. Linguist. English Lit. 5, 122-126

Singh, R. (2018). Derivational Grammar Model and Basket Verb: A Novel Approach to the Inflectional Phrase in the Generative Grammar and Cognitive Processing. English Linguistics Research, Vol.7, No.2. https://doi.org/10.5430/elr.v7n2p9

Singh, R. (2018). A Cognitive Approach to the Semantics in the Sacred Context: Semantic and Symbolic Function of Sacred Words. English Linguistics Research, Vol.7, No.3. https://doi.org/10.5430/elr.v7n3p1

Singh, R. (2018). Norwegian and Persian spatial prepositions: a novel comparative and syntactic approach to the spatial prepositions. KAAV international journal of English, literature, and linguistics, vol.5/ page no.1-8. Retrieved from: http://www.kaavpublications.org/journals/journal-5/article/article-1788.pdf

Singh, R. (2018). Areas of errors and difficulty for persian learners of spanish caused by the sound system differences between persian and spanish: a phonetic approach to inter-lingual system. KAAV international journal of English, literature, and linguistics, vol.5/ page no.1-8. Retrieved from: http://www.kaavpublications.org/journals/journal-5/abstract/abstract-1996.pdf

Singh, R. (2018). Mirroring Effects and the Water Code: A Cognitive-Semantic Approach to Natural Morphology in the Religious-Cultural Context. Journal of Literature, Languages and Linguistics, vol.46/page no.37-41. Retrieved from: https://iiste.org/Journals/index.php/JLLL/article/download/43453/44769

Singh, R. (2018). Russian and Negative Prefixing: A Cognitive-Semantic Approach to the Negative Adjective 
Prefixing in Russian, Spanish, Persian, and English. English Linguistics Research, Vol.7, No.4. https://doi.org/10.5430/elr.v7n4p7

Singh, R. (2018). Auxiliary Verbs in Serbo-Croatian, French, Persian, Spanish and English: A CognitiveSemantic Approach to the Auxiliary Verb Usage and Passive Voice. English Linguistics Research, Vol.7, No.3. https://doi.org/10.5430/elr.v7n3p34

Singh, R. (2018). Language change and directionality: A novel model for language change in Persian and Iranian languages from the sociolinguistic perspective. KAAV International journal of English, Literature, and linguistics, vol.5/page no.1-8. Retrieved from: http://www.kaavpublications.org/journals/journal5/article/article-1876.pdf

Singh, R. (2018). Error Analysis of Persian Learners of Hausa Language: Cognitive Approach to Errors. Journal of Literature, Languages and Linguistics, vol.45/page no.10-15. Retrieved from: https://iiste.org/Journals/index.php/JLLL/article/view/42853/44147

Singh, R. (2018). Albanian World-View: Co-Locativity as the Schematic Meaning of Albanian Verbal Prefix Bashke-. English Linguistics Research, Vol.7, No.4.

Singh, R. (2018). Christian And Sikh Communities In Iran And Role Of Language Identity: A Comparative Approach To The Social-Linguistic Aspects Of The Christianity And Sikhism In The Middle East. Sikh Research Journal, Vol.3, No.1.

Toribio, A. J. (2004). Spanish/English speech practices: Bringing chaos to order. Bilingual Education and Bilingualism, 7, 133-154. 